\title{
THE COVID-19 PANDEMIC: A TRANSFORMATIVE LEARNING FROM A FAITH-BASED PHILANTHROPIC ORGANIZATION
}

\author{
Bambang Edi Prasetyo ${ }^{1}$, Erica Yunita Trisnawati ${ }^{1)}$, Latifah \\ Alifiana Rahmawati'), Mutiara Tirta P L Kusuma') \\ 1)Dompet Dhuafa Foundation, Yogyakarta Branch, Indonesia \\ ${ }^{2}$ Department of Nutrition and Health, Faculty of Medicine, \\ Public Health, and Nursing, Universitas Gadjah Mada, Indonesia
}

\begin{abstract}
Background: COVID-19 pandemic poses various challenges to any organization to maintain their work due to prolonged movement restriction and the ambiguity surrounding its end. Dompet Dhuafa Yogyakarta, a philanthropic organization based on Islam, has implemented changes to ensure service delivery and their reach to the targeted populations. This study aimed to identify the way Dompet Dhuafa Yogyakarta adapt with changes as well as explore innovation, best practice, and lesson learned.

Subjects and Method: This was a qualitative case study conducted at Dompet Dhuafa Yogyakarta, from June to October, 2021. The informants included branch manager, head of health program, and project assistant. The data were collected through focus group discussion. The data were analyzed according to themes (thematic analysis) using the IPO logic model (input-process-output) as a framework for analysis.

Results: Three major themes emerged: (1) Surviving the pandemic; (2) Making greater contributions; and (3) Ensuring sustainability. Several changes had been made in order to sustain the work of Dompet Dhuafa Yogyakarta and achieve organizational mission as part of crisis exit strategies. Crisis management was a part of strategic management aiming at ensuring organizations survive during major disruption. As part of the crisis responses, Dompet Dhuafa Yogyakarta implemented adaptive approaches by initiating new projects, collaborating with new partners, and diversifying funding sources. The key informants also stated that the digital technology was low-cost, flexible, sustainable, and was able to reach the poor population. The digital technology could be used to help support the newly implemented telemedicine and social media-based health education programs.

Conclusion: This study highlights how Dompet Dhuafa Yogyakarta responded to the pandemic. Several changes have been made in order to sustain their work and achieve organizational mission as part of crisis exit strategies. Lessons learned should be taken from this pandemic to develop future emergency preparedness plans.
\end{abstract}

Keywords: crisis management, emergency preparedness, exit strategy, COVID-19, faith-based philanthropic organization

\section{Correspondence:}

Mutiara T P L Kusuma. Department of Nutrition and Health, Faculty of Medicine, Public Health, and Nursing, Universitas Gadjah Mada. Jl. Farmako, Sekip Utara, Yogyakarta 55281 Indonesia. Email: mutiara.tirta@gmail.com. Mobile: 081398803205. 